\title{
Field Screening of Pigeon Pea (Cajanus cajan) for resistance to foliar diseases in Puerto Rico. ${ }^{1}$
}

\author{
Rocio Rodríguez and P. L. Meléndez ${ }^{2}$ \\ ABSTRACT
}

Pigeon pea (Cajanus cajan) accessions from the world collection, cultivars and local advanced lines from the UPR breeding program were field screened for resistance to foliar diseases at the Isabela Research and Development Center. Uredo cajani, Colletotrichum sp., Cercospora sp. and Phoma sp. were identified as the major foliar pathogens present in the area. Forty eight of the 3286 accessions evaluated showed low incidence of foliar diseases. Of the local lines, line 64-16A showed the fewest foliar symptoms; line 8-AB-2 was the most susceptible within the group evaluated.

\section{INTRODUCTION}

Pigeon pea (Cajanus cajan (L.) Millsp.) is a valuable tropical legume that thrives even in marginal lands which are usually unfit for cultivation of many other crops. It is the main agricultural crop in several regions of the Island, especially in the hills and on the southern slopes of the Central Mountain Range. This protein-rich legume is the most important edible one grown commercially in Puerto Rico. Duke (1) reported that at zero moisture, dry and green pigeon pea seeds contain more than $20 \mathrm{~g}$ of protein per $100 \mathrm{~g}$.

Pigeon peas are produced mainly for canning and for the fresh market. In $1981-1982$, the farm value of the crop was estimated to be around $\$ 5.5$ million. ${ }^{3}$

Diseases are serious threats to most agricultural enterprises. Williams (6), Tucker (5), Saksena and Kumar (4), and Mueller and Chupp (3), report rust (Uredo cajani), anthracnose (Collectotrichum sp.) and leaf spots (Cercospora sp., Phoma sp.) as foliar diseases which might endanger the continued successful production of pigeon peas in some areas of the world. Kannaiyan et al. (2) reported that in Puerto Rico these diseases are of no consequence, but it is well known locally that when environmental conditions are favorable these pathogens cause defoliation, poor yield and poor seed quality. The identification and utilization of disease resistance is an important strategy for preventing commercial losses from disease epidemics.

Results on the screening of the pigeon pea germplasm and local advanced lines for resistance to these foliar diseases are herein reported.

\footnotetext{
${ }^{1}$ Submitted to Editorial Board August 10, 1983.

${ }^{2}$ Research Assistant and Phytopathologist, Department of Crop Protection, University of Puerto Rico, Mayagüez, Puerto Rico 00708.

${ }^{3}$ Personal communication from Agricultural Statistics, P.R. Department of Agriculture.
} 


\section{MATERIALS AND METHODS}

During 1977, 1978, and 1980, at the Isabela Research and Development Center, the pigeon pea germplasm world collection was field-screened for resistance to foliar diseases caused by Uredo cajani, Colletotrichum sp., Cercospora sp. and Phoma sp. A total of 3,286 accessions from the germplasm world collection, two commercial varieties, and 13 advanced lines were included in the study. Test stands consisted of 5 to 10 plants of each line which were rated after 5 months of growth. Screening was based on natural infection. In the 1980 test, spreader rows of pigeon pea rust susceptible cv. 98 were planted as borders to increase rust severity. Plants were visually evaluated and rated on the basis of the percentage of foliage affected as follows: $0=$ no disease; $1=1-20 \% ; 2=21-40 \%$; $3=41-60 \% ; 4=61-80 \% ; 5=81-100 \%$. Each line was tested for the presence of rust and foliar spots. Degrees of foliar spots were estimated irrespective of the causal organism. During the first stages of plant development, weeds were controlled by hand-weeding and no fertilization was used. Insects were kept under control by foliar applications of Lannate $\mathrm{L},{ }^{4} 2.34$ 1/ha. Temperature and rainfall data were recorded.

\section{RESULTS AND DISCUSSION}

\section{ADVANCED LINES AND COMMERCIAL CULTIVARS}

There was a distinct difference in field reaction of pigeon peas advanced lines and cultivars to foliar diseases (table 1). Showing less than $20 \%$ severity lines 64-16 A, Am. × Kaki, 69-58-I, 16 A Irr. and cv. Kaki appeared most resistant to rust attack. Conversely, showing symptoms in more than $80 \%$ of its foliage, line $8-\mathrm{AB}-2$ was very susceptible. When screened for other foliar pathogens, less than $40 \%$ of the exposed surface of lines 64-16-A, 7, 64-21-B-2 and 69-52 was invaded. Line Am. $\times$ Kaki, which appeared somewhat resistant to rust was severely attacked by other foliar pathogens. Pigeon peas line 8-AB-2 was equally susceptible to all the foliar diseases studied. Line 64-16-A proved to be outstanding for its resistance to rust and other foliar pathogens.

\section{Germplasm COLLECTION}

None of the accessions tested were free from rust infection. Nevertheless, most accessions (2,203), showed $20 \%$ or less rust severity. Among 1,083 accessions, symptoms were observed in more than $40 \%$ of their

\footnotetext{
${ }^{4}$ Trade names in this publication are used only to provide specific information. Mention of a trade name does not constitute a warranty of equipment or materials by the Agricultural Experiment Station of the University of Puerto Rico, nor is this mention a statement of preference over other equipment or materials.
} 
foliage; and among 21 accessions, in more than $80 \%$ (table 2). As to foliar spots, 396 accessions appeared free of symptoms; 985 were slightly attacked; and 755 were moderately attacked by the pathogens. More than $40 \%$ of the foliage of the remaining 1,150 accessions was invaded by the pathogens, (table 3 ).

Out of the total accessions evaluated, 48 appeared to have high levels of resistance to both rust and other foliar pathogens in Puerto Rico (table 4). These accessions could serve as important parental material for breeding pigeon peas resistant to these foliar diseases.

TABLE 1.-Reaction of several cultivars and advanced lines of pigeon peas to invasion by Uredo cajani, Colletotrichum $s p$. , Cercospora $s p$. and Phoma $s p$

\begin{tabular}{lcc}
\multicolumn{1}{c}{$\begin{array}{c}\text { Advanced lines } \\
\text { and cultivars }\end{array}$} & \multicolumn{2}{c}{ Rating } \\
\cline { 2 - 3 } 64-16 A & Rust & Foliar spots \\
Am. $\times$ Kaki & 1 & 1 \\
69-58-I & 1 & 5 \\
7 & 1 & 3 \\
Kaki $\times$ GI-27-4-A & 3 & 2 \\
8-AB-2 & 3 & 5 \\
64-21 B-2 & 5 & 5 \\
OP-61 & 3 & 2 \\
73-IBD & 3 & 3 \\
16 A Irr & 3 & 3 \\
69-52 & 1 & 3 \\
142 A & 3 & 2 \\
2-B-Bushy & 3 & 3 \\
Kaki & 3 & 3 \\
Tal & 2 & 3 \\
\hline
\end{tabular}

${ }^{\mathrm{I}}$ Commercial cultivars.

During the years of evaluation, fluctuations in mean maximum and mean minimum temperatures, as well as in rainfall, were measured. Slight differences between mean temperatures were observed (table 5). In 1980 there was the biggest difference $\left(10^{\circ} \mathrm{C}\right)$ between day and night temperatures; in 1978 , the smallest difference $\left(8.7^{\circ} \mathrm{C}\right)$. Fluctuations in rainfall were wider: $18.0 \mathrm{~mm}$ was recorded in 1977; $34.4 \mathrm{~mm}$ in 1978; and $18.0 \mathrm{~mm}$ in 1980 . Nevertheless, according to the symptoms expressed in susceptible lines, these differences apparently did not interfere with the viability and level of inoculum present in the field. Coincidentally, in 1980, the warmer year with less rain, the range of resistance to the attack of these pathogens was wider (tables 2 and 3 ). Since difference accessions were evaluated, their response to the presence of foliar diseases could be expected to be different in different years. Moreover, it is significant that 
in 1980, rows of spreader-susceptible cv. 98 were used. This suggests that, apparently, the use of spreader rows greatly helped to enhance disease stress on lines within the experimental plots.

\section{RESUMEN}

En los años 1977, 1978 y 1980 se evaluó para resistencia a enfermedades foliares la colección mundial de germoplasma de gandul y algunas

TABLE 2.-Population per rating of accessions tested for resistance to the incasion of Uredo cajani during the years of evaluations

\begin{tabular}{crrrr}
\hline & \multicolumn{3}{c}{ Population of accessions } \\
\cline { 2 - 4 } Rating & \multicolumn{3}{c}{ Years } & Total \\
\cline { 2 - 4 } & 1977 & 1978 & 1980 & 0 \\
0 & 0 & 0 & 0 & 738 \\
1 & 186 & 109 & 443 & 1,465 \\
2 & 759 & 319 & 387 & 926 \\
3 & 500 & 237 & 189 & 136 \\
4 & 17 & 53 & 66 & 21 \\
5 & 0 & 0 & 21 & 3,286 \\
Total & 1,462 & 718 & 1,106 & \\
\hline
\end{tabular}

TABLE 3.-Population per rating of accessions tested for resistance to the invasion of Colletotrichum sp., Cercospora sp., and Phoma sp. during the years of evaluation.

\begin{tabular}{crrrr}
\hline & \multicolumn{3}{c}{ Population of accessions } \\
\cline { 2 - 3 } Rating & \multicolumn{3}{c}{ Years } & Total \\
\cline { 2 - 3 } & 1977 & 1978 & 1980 & 396 \\
0 & 4 & 0 & 392 & 985 \\
1 & 425 & 5 & 555 & 755 \\
2 & 543 & 146 & 66 & 947 \\
3 & 474 & 428 & 45 & 178 \\
4 & 15 & 139 & 24 & 25 \\
5 & 1 & 0 & 24 & 3,286 \\
\hline
\end{tabular}

variedades y líneas avanzadas obtenidas del proyecto de fitomejoramiento. El material se evaluó contra enfermedades foliares causadas por Uredo cajani, Colletotrichum sp., Cercospora sp. y Phoma sp. Se examinaron 3,286 líneas de la cuales 48 resistieron mejor la invasión de estos patógenos. Entre el grupo de líneas avanzadas y cultivares de gandul evaluadas, la línea 64-16 A mostró síntomas de estas enfermedades en menos de $20 \%$ de su follaje, mientras que la línea $8-A B-2$ fue la más susceptible. 
TABLE 4.-Outstanding field screened accessions from pigeon pea germplasm world collection for resistance to foliar pathogens

\begin{tabular}{llccc}
\hline \multicolumn{5}{c}{ Accession No. ${ }^{\mathbf{1}}$} \\
\hline 394000 & 394470 & 396202 & 397198 & 397894 \\
394002 & 394520 & 396232 & 397208 & 397902 \\
394003 & 394571 & 396316 & 397209 & 397907 \\
394005 & 394580 & 396352 & 397218 & 399635 \\
394016 & 394581 & 396531 & 397237 & \\
394102 & 394582 & 396749 & 397246 & \\
394148 & 394583 & 396765 & 397248 & \\
394172 & 394635 & 396962 & 397251 & \\
394421 & 394851 & 396968 & 397305 & \\
394429 & 396199 & 396970 & 397380 & \\
394468 & 396200 & 397030 & 397872 & \\
\hline
\end{tabular}

${ }^{1}$ Numbers of accessions correspond to USDA-PIN. They were received through the S-9 Regional Project.

TABLE 5.-Mean temperature and rainfall during the periods preceding the evaluations

\begin{tabular}{|c|c|c|c|}
\hline \multirow{2}{*}{ Year } & \multicolumn{2}{|c|}{ Mean Temperature } & \multirow{2}{*}{$\begin{array}{l}\text { Rainfall } \\
\text { mm }\end{array}$} \\
\hline & Maximum & Minimum & \\
\hline 1977 & 29.2 & 19.2 & 18.0 \\
\hline 1978 & 28.5 & 19.8 & 34.4 \\
\hline 1980 & 30.6 & 21.4 & 8.4 \\
\hline
\end{tabular}

\section{LITERATURE CITED}

1. Duke, J. A., 1981. Handbook of Legumes of World Economic Importance, Plenum Press, New York.

2. Kannaiyan, J., Y. L. Nene, M. V. Reddy and T. N. Raju, 1981. International survey of pigeon pea diseases. ICRISAT (International Crops Research Institute for the SemiArid Tropics)

3. Muller, A. S. and C. Chupp, 1942. Las Cercospora de Venezuela. Bot. Soc. Venez. Cienc. Nat. 8 (52):35-9. (Abst. 1001) An Annotated Bibliography of Pigeon Peas. B. S. Dahiya. ICRISAT.

4. Saksena, H. K. and K. Kumar, 1971. Some aspects of epidemiology and control of Phyllosticta leaf spot of arhar (Cajanus cajan (L.) Millsp.). Proc. Nat. Acad. Sci. India (Sect. B.) 37 (6): 399-406. (Abst. 1063). An Annotated Bibliography of Pigeon Pea. B. S. Dahiya. ICRISAT.

5. Tucker, C. M., 1927. Pigeon pea anthracnose, J. Agric. Res. 34 (6): 589-96.

6. Williams, R. J. and D. J. Allen, 1976. Grain legume training course, Pathology, IITA, Ibadan, Nigeria. (Abst. 1134) An Annotated Bibliography of Pigeon Pea. B. S. Dahiya. ICRISAT. 